\title{
Medievalista
}

Online

$24 \mid 2018$

Número 24

\section{O casamento de Leonor e Frederico III (1451-1452) e as relações entre Portugal e o Sacro Império nos finais da Idade Média}

The marriage of Leonor and Frederick III (1451-1452) and the relations between Portugal and the Holy Empire in the late Middle Ages

\section{António Martins Costa}

\section{OpenEdition}

\section{Journals}

\section{Edição electrónica}

URL: http://journals.openedition.org/medievalista/1703

DOI: $10.4000 /$ medievalista. 1703

ISSN: 1646-740X

\section{Editora}

Instituto de Estudos Medievais - FCSH-UNL

\section{Refêrencia eletrónica}

António Martins Costa, « O casamento de Leonor e Frederico III (1451-1452) e as relações entre

Portugal e o Sacro Império nos finais da Idade Média », Medievalista [Online], 24 | 2018, posto online no dia 16 março 2019, consultado no dia 20 abril 2019. URL : http://journals.openedition.org/ medievalista/1703 ; DOI : 10.4000/medievalista.1703

Este documento foi criado de forma automática no dia 20 Abril 2019.

(C) IEM 


\section{O casamento de Leonor e Frederico III (1451-1452) e as relações entre Portugal e o Sacro Império nos finais da Idade Média}

The marriage of Leonor and Frederick III (1451-1452) and the relations between Portugal and the Holy Empire in the late Middle Ages

António Martins Costa

\section{NOTA DO EDITOR}

Data recepção do artigo / Received for publication: 23-03-2017

Data aceitação do artigo / Accepted in revised form: 17-05-2018

Cabendo ao casamento um decisivo papel na fundação de relações de aliança, era através dele que se materializavam e reforçavam as associações e compromissos entre famílias. ${ }^{1}$

\section{Introdução}

1 O casamento do imperador Frederico III e da infanta D. Leonor, celebrado entre $1451 \mathrm{e}$ 1452, chegou aos nossos dias documentado por uma invulgar diversidade de fontes, entre documentos, crónicas e iconografia. Se por um lado a riqueza de registos é reveladora da importância daquele enlace tardo-medieval, por outro explica a atenção que a historiografia lhe tem vindo a dedicar na contemporaneidade. Permitimo-nos destacar trabalhos como os do visconde de Santarém $(1842)^{2}$ e de Sousa Viterbo $(1894)^{3}$, que no século XIX lograram um importante esforço ao nível da pesquisa e da transcrição de fontes; num segundo momento, em plena Segunda Guerra Mundial, salientou-se o estudo 
de Alfredo Gama e E. A. Strasen $(1944)^{4}$, que, ao procurarem demonstrar a antiguidade das relações luso-alemãs, deram a conhecer a princesa lusa que se sentou no trono do distante Império; mais recentemente, trabalhos como os de Antonia Hanreich (1985) ${ }^{5}$, de Maria Helena Coelho $(2003)^{6}$ e de Adriana Almeida (2007) ${ }^{7}$, mercê da valorização da história das relações internacionais nos últimos trinta $\operatorname{anos}^{8}$, vieram abrir caminho na óptica da política das dinastias de Avis e de Habsburgo.

Com recurso a fontes portuguesas, alemãs e aragonesas, o nosso estudo, focado no matrimónio do rei dos romanos e da infanta lusa, pretende dar (mais) um contributo para o conhecimento das relações entre duas monarquias que, apesar de geograficamente distantes, se aproximaram politicamente nos finais da Idade Média. Assim, em jeito de enquadramento, procuraremos descortinar como, sobre o pano de fundo da velha Cristandade em transformação, se urdiram as estratégias de aliança que conduziram ao interesse de um matrimónio real entre Portugal e o Sacro Império Romano-Germânico. De seguida, acompanharemos o processo negocial do enlace entre ambas as monarquias, mediado pelo reino de Nápoles, num período em que se registam francos progressos na prática da diplomacia. Por fim, observaremos as etapas da preparação e da celebração do casamento régio, acontecimento simultaneamente religioso e político, concluindo com os impactos trazidos pela nova era de relações entre a dinastia de Avis e os Habsburgo às portas da Modernidade.

\section{Os jogos das alianças na Europa tardo-medieval}

3 Sob o signo da guerra, da fome e da peste, o final da Idade Média correspondeu a um período de grandes transformações na Europa. Na primeira metade do século XV, como notou Jorge Borges de $\mathrm{Macedo}^{9}$, as mais diversas unidades políticas direccionaram-se num processo de centralização de poder no interior dos territórios e num alargamento das suas fronteiras, sob a vigilância de um Papado que, logrando a unidade da Igreja no Concílio de Constança (1414-1418), procurou manter o seu papel arbitral. No coração da Cristandade, a França e a Inglaterra, na frente das respectivas alianças, prolongavam a Guerra dos Cem Anos (1337-1453); a leste, somando vitórias sucessivas, os turcos otomanos avançavam sobre Bizâncio e a Hungria, ameaçando as próprias repúblicas italianas; a oeste, na Península Ibérica, Castela, que ali exercia uma força centrípeta, apostava na conquista de Granada, enquanto Aragão e Portugal encontravam saída no mar, respectivamente, o Mediterrâneo e o Atlântico ${ }^{10}$. 
Figura 1 - A Europa na primeira metade do século XV (c. 1430)

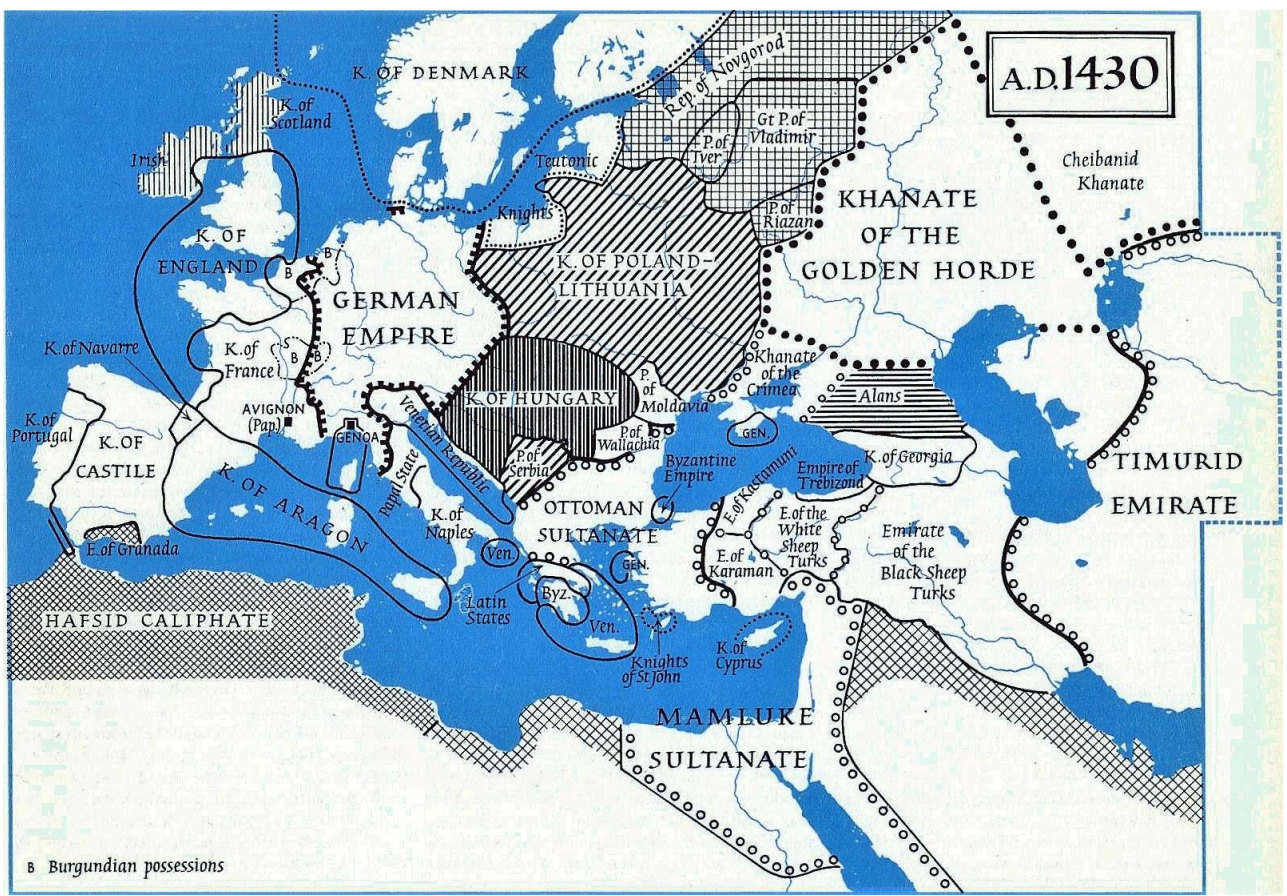

Fonte: MCEVEDY, Colin - The Penguin Atlas of Medieval History. Harmondsworth: Penguin Books Ltd., 1976, p. 83.

A dimensão destes conflitos na Cristandade obrigava, pois, a uma acção diplomática cada vez mais regular e cuidada, capaz de, através de diversos meios e agentes, fazer e desfazer acordos nas mais voláteis circunstâncias. Sobre um xadrez político maioritariamente monárquico, os matrimónios entre casas reinantes revelavam-se peças-chave no jogo das relações internacionais. Afinal, conforme afirmou Ana Maria Rodrigues ${ }^{11}$, os casamentos régios tardo-medievais eram fundamentais para evitar a extinção biológica, assegurar a continuidade da linhagem, preservar o poder, ampliar o património e, claro, selar alianças.

Em Portugal, a dinastia de Avis, instituída no final do século XIV através da escolha em Cortes de um filho natural, não esqueceu a importância dos enlaces régios no seu multifacetado processo de afirmação ${ }^{12}$. Pela mão do fundador, conseguimos vislumbrar logo após a Crise de 1383-1385 o desenvolvimento de uma ampla estratégia matrimonial, que podemos agrupar em etapas. Em primeiro plano, tirando partido da Guerra dos Cem Anos, podemos situar uma "etapa inglesa", com os casamentos do próprio D. João I com D. Filipa de Lencastre, em 1386, e de D. Beatriz, filha natural do rei de Boa Memória, com Thomas Fitzalen, conde de Arundel, em $1405^{13}$. Depois, aquando do dissídio de Castela com o seu vizinho oriental por causa das perturbações senhoriais provocadas pelos "infantes de Aragão", podemos considerar uma "etapa aragonesa" com os casamentos, em 1428, do infante herdeiro D. Duarte com D. Leonor, irmã do rei de Aragão D. Afonso V, e do infante D. Pedro com D. Isabel, filha do conde de Urgel, D. Jaime (derrotado e aprisionado na luta pelo trono aragonês por D. Fernando I, pai da referida D. Leonor). Por último, podemos ainda aceitar um "etapa borgonhesa" com o casamento, celebrado em 1430, da infanta D. Isabel com Filipe, o Bom, duque da Borgonha, união que, de alguma forma, vinha exercer pressão sobre a Coroa francesa e, mais uma vez, sobre a monarquia castelhana, tendencialmente aliada da França no grande conflito. Um ano volvido, a 30 de 
Outubro de 1431, a assinatura da paz perpétua em Medina del Campo veio afastar definitivamente as reivindicações castelhanas sobre a coroa do velho D. João I ${ }^{14}$. Porém, a dinastia de Avis não cessaria o processo do seu reconhecimento como casa reinante na esfera da Cristandade.

O sucessor do monarca de Boa Memória, D. Duarte, houve do casamento com D. Leonor de Aragão dois filhos e três filhas que chegariam à idade adulta, dos quais alguns se iriam revelar da maior importância para a diplomacia portuguesa. Subido ao trono em 1433, o Eloquente morreu subitamente ao cabo de cinco anos de reinado, em Tomar, vítima de um surto de peste ${ }^{15}$. Teve então lugar uma acicatada disputa entre a rainha viúva e o cunhado mais velho, D. Pedro, pela regência do reino e pela tutoria do herdeiro, o pequeno D. Afonso, conflito esse que viria a culminar na vitória do partido do duque de Coimbra e no exílio castelhano de D. Leonor em 1441. Nos anos que mediaram até à sua morte, ocorrida em 1445, esta alimentou a recuperação do que considerava seu por direito em Portugal, procurando apoio junto dos irmãos, os ditos "infantes de Aragão", insistindo sobretudo com aqueles que se sentavam nos restantes tronos cristãos peninsulares: D. Maria, rainha consorte de Castela; D. João, monarca consorte de Navarra; e D. Afonso V, rei de Aragão, que por esses anos se empenhava na conquista da monarquia napolitana. Mas no reino castelhano a conjuntura não corria de feição à viúva de $\mathrm{D}$. Duarte, na medida em que os seus irmãos, que aí possuíam vastos senhorios, combatiam o governo centralizador do rei D. João II, coadjuvado pelo condestável D. Álvaro de Luna, que depressa beneficiou de apoio militar do regente português para a Batalha de Olmedo de 1445, onde bateu os seus opositores. Contando os "infantes de Aragão" como inimigos comuns, o rei de Castela, enviuvando nesse ano, reforçou os laços de amizade com Portugal ao aceitar em casamento a jovem D. Isabel, filha do falecido infante D. João ${ }^{16}$. Mas a estratégia matrimonial do regente não se esgotou nesta sua sobrinha.

O infante D. Pedro tinha desde cedo compreendido a importância política dos enlaces matrimoniais. Logo após a morte do irmão, e antes da ruptura com D. Leonor, tinha concertado o casamento do rei menino, D. Afonso V, com a sua filha D. Isabel. Agora que combatia os "infantes de Aragão", procurava alternativas ao equilíbrio peninsular alémPirenéus oferecendo em matrimónio a mão das infantas D. Leonor e D. Joana. Sensivelmente a partir de 1445 , segundo Luciano Cordeiro ${ }^{17}$, o regente português projectava os casamentos destas sobrinhas, respectivamente, com o delfim de França, Luís, e com o neto do falecido imperador Segismundo III $^{18}$, Ladislau, contando para o efeito com a cumplicidade da irmã, D. Isabel da Borgonha, que procurava capitalizar estes enlaces para aproximar o seu ducado das duas monarquias que conhecia por suseranas: se por um lado lhe era conveniente regularizar as boas relações com a França, uma vez que se adivinhava a sua vitória na Guerra dos Cem Anos, por outro urgia reparar os prejuízos infligidos aos Habsburgo, a quem recentemente Filipe, o Bom, havia anexado o Luxemburgo. Só que a roda da fortuna levaria a que neste xadrez as peças fossem jogadas noutra direcção, assim como pela mão de outra facção.

8 Em Portugal, no mês de Julho de 1448, o infante D. Pedro abandonou definitivamente a regência do reino e retirou-se para o ducado de Coimbra ${ }^{19}$. Mau grado a omissão do cronista Rui de Pina ${ }^{20}$, mais preocupado em narrar a agudização das relações entre o exregente e o duque de Bragança que se seguiu, sabemos por cartas da rainha de Aragão, datadas de 14 de Outubro daquele ano, do interesse do próprio imperador, Frederico III, em contrair matrimónio com uma infanta portuguesa ${ }^{21}$. Nesses documentos, dirigidos às cortes de Castela, de Navarra e de Portugal, recomendava-se o acolhimento a uma 
embaixada imperial com destino a este último reino, a qual seria encabeçada pelo barão austríaco Jorge de Volrestorf e pelo cónego de Augsburg Ulderico Riedrer - atente-se, nos finais da medievalidade, à corrente complementaridade de um nobre e de um eclesiástico nas missões diplomáticas, tendo em vista a honra e o saber que a representação régia exigia $^{22}$.

Então, Frederico de Habsburgo, filho dos duques Ernesto e Cimburga da Áustria, contava já trinta e três anos de idade, e havia nove que fora eleito rei dos romanos. Encontrava-se empenhado em consolidar o seu domínio sobre o território imperial, um fragmentado mosaico de cidades e principados autónomos que se espraiava do norte da Península Itálica ao Mar Báltico ${ }^{23}$. Mas, para o efeito, urgia selar matrimónio e garantir descendência. Após várias tentativas de casamento falhadas na Europa central ${ }^{24}$, Frederico parece ter colocado todo o empenho na preparação da embaixada que visitou a Corte lusa na viragem de 1448 para 1449, muito provavelmente incluindo nela um pintor, de nome desconhecido, para captar as características físicas das infantas de Avis ${ }^{25}$. Afinal, embora distante, Portugal não era uma aliança a desconsiderar, visto afamar-se por esses anos com a expansão em Marrocos, a colonização de algumas ilhas atlânticas e a exploração da costa africana até à zona dos negros, de onde começavam a afluir as primeiras riquezas ${ }^{26}$. Havia, pois, que aproveitar a mediação do soberano Magnânimo.

De facto, o projecto matrimonial chegava agora pela mão de D. Afonso V de Aragão e Nápoles, rival do infante D. Pedro, que procurava concertar-se com o jovem rei de Portugal, seu sobrinho e homónimo. Para a protecção das suas possessões italianas, constantemente ameaçadas pela França e pelo Papado, convinha ao monarca aragonês uma aproximação ao Sacro Império. Sem descendência legítima para oferecer em casamento, não admira o seu esforço de apadrinhamento de um enlace luso, ao ponto de se vir a assumir, por carta, como tutor dos filhos da sua falecida irmã, em especial da infanta D. Leonor, a quem afirmou amar não como sobrinha, mas como "propria fija" ${ }^{27}$. Nascida em Torres Vedras a 18 de Setembro de 1434, esta infanta ${ }^{28}$ contaria catorze anos aquando da vinda da embaixada de Frederico III a Portugal, sendo, pela idade núbil, a que desde logo mais interesse terá despertado para o enlace, uma vez que D. Catarina e D. Joana eram, respectivamente, dois e cinco anos mais novas ${ }^{29}$. 0 rei português, seu irmão, por muito que preferisse uma união com o delfim da poderosa França, não escamotearia a oportunidade de um casamento imperial. Por ora, Frederico III dera um primeiro passo; as circunstâncias em Portugal trariam D. Afonso V ao seu encontro.

11 Entre o final de 1448 e os primeiros meses do ano seguinte extremam-se os partidos do infante D. Pedro e do duque D. Afonso de Bragança, seu meio-irmão, que manobra profundamente na corte em torno do rei. A tensão culmina a 20 de Maio de 1449 na Batalha de Alfarrobeira, da qual a hoste régia sai vitoriosa sobre a do ex-regente, que acaba morto e insepulto no campo $^{30}$. No reino, sucedem-se as confiscações e as perseguições aos seguidores do duque de Coimbra, resultando na prisão dos seus próprios filhos D. João e D. Jaime; no estrangeiro, agitam-se algumas cortes, como foi o caso da Borgonha, cujos duques censuram o rei português pelo tratamento indigno dos restos mortais de D. Pedro e pelo encarceramento dos seus descendentes, chegando mesmo a apelar para o Papado ${ }^{31}$. É o momento de D. Afonso V responder interna e externamente com a afirmação da sua realeza. Então, que mais conveniente do que fortalecer o prestígio da sua estirpe alcandorando-a ao mais alto patamar da Cristandade? 


\section{As cuidadas negociações da diplomacia luso-alemã} mantinha relações diplomáticas com catorze ou quinze unidades políticas, sendo boa parte dessas ligações reforçada por vínculos de parentesco mais ou menos próximo com as respectivas casas, o que se verificava em relação a Castela, Aragão, Navarra, Borgonha, Bretanha, Inglaterra e Escócia ${ }^{32}$. Escapava a este universo o longínquo Sacro Império, cujos contactos com a monarquia portuguesa não tinham ido muito além da passagem de cruzados durante a Reconquista, do estabelecimento de comércio com algumas cidades hanseáticas nos finais de Trezentos e, mais recentemente, da participação de barões germânicos na conquista de Ceuta ${ }^{33}$. Lograr tirar partido do interesse matrimonial do Rex Romanorum representaria, pois, um passo de gigante da diplomacia lusa, não tanto pelo seu poderio, mas pelo prestígio da sua Coroa - assumindo-se sucessor dos césares romanos, árbitro da Cristandade e protector do Papado, o imperador continuava a ser reconhecido, em teoria, como a primeira autoridade temporal da Europa medieva ${ }^{34}$. Assim sendo, no contexto da crispada crise pós-Alfarrobeira, decerto que o rei de Portugal se encontrava tão interessado quanto preparado para dar sequência a um segundo contacto imperial.

De acordo com a Crónica do Senhor Rey D. Affonso V, encontrando-se a corte régia em Évora "na entrada do ano de myl e quatrocentos e cinquoenta, ouve cartas do Emperador d'Allemanha Frederico, que entam se chamava Rey dos Romaaõs" pois, explicita o cronista, "lhe prazia casar com a Ifante Dona Lionor sua Irmaã" ${ }^{35}$. Certamente convencido pelas descrições físicas e morais transmitidas pela sua embaixada ${ }^{36}$, além de animado "per ElRey Dom Affonso Rey de Napolles e d'Aragam" ${ }^{37}$, o imperador declarava expressamente o desejo de casar com a mais velha das infantas de Avis, tal como seria expectável.

era irresistível. Abandonando definitivamente a hipótese do matrimónio francês, como havia preconizado o seu tio e ex-regente, D. Afonso V prontamente avaliou a proposta de Frederico III e preparou-se para encetar negociações. Contudo, estas não teriam lugar, como era comum, no território de uma ou de outra monarquia, mas num lugar aparentemente neutro: a corte de Nápoles. Sabemos que assim o desejava o imperador, talvez pela quase inexistência de relações com Portugal, e certamente o rei aragonês, mais seguro de os trabalhos chegarem a bom porto sob o seu patrocínio ${ }^{38}$.

Urgia agora instruir e mandatar as embaixadas, criteriosamente escolhidas pelos respectivos soberanos tendo em conta as garantias de preparação e de lealdade ao seu serviço. Temos notícia de que a 27 de Junho daquele ano, por carta dada em Lisboa, D. Afonso V investiu com "inteiro poder" de procurador "o nobre fidalgo João Fernandes da Silveira, egrégio doutor em Leis" ${ }^{39}$, atestando a importância da dedicada aristocracia de toga numa diplomacia que se alicerçava no direito ${ }^{40}$. Três meses depois, a 25 de Setembro, foi a vez de Frederico, por procuração passada em Neustadt, creditar os seus conselheiros D. Eneias, bispo de Trieste (e futuro Papa Pio II), e D. Jorge de Vollesdorf, barão austríaco, bem como o secretário Miguel de Phullendorf, para tratar com os delegados do rei de Portugal um matrimónio, conforme se afirmava detalhadamente, "segundo rito e costume da Santa Madre Egreja" ${ }^{41}$. Afinal, os esponsórios a estabelecer em Nápoles deveriam ser modelares segundo os cânones civis e eclesiásticos para, no dizer de Maria Helena Coelho, "servirem de exemplum legitimador" 42 do rei de Portugal e do Algarve e senhor de Ceuta e do imperador, rei dos romanos. 
16 As embaixadas reúnem-se em Outubro diante do rei Magnânimo. Entre praxes e formalismos, apresentam as respectivas credenciais à corte napolitana, reconhecendo a mediação do monarca aragonês e anunciando a legitimidade jurídica dos procuradores para tratar, concluir e contrair o acordo matrimonial ${ }^{43}$. Tem então lugar a ronda negocial prévia das capitulações, que, ao arrastar-se por quarenta dias, deixa perceber como aquelas terão sido bastante ponderadas ${ }^{44}$. De facto, a parada era elevada. Ao cabo de várias sessões de análise e discussão, e sempre na presença de conselheiros do rei de Nápoles, os embaixadores foram tecendo o contrato de casamento, que se veio a assinar com todo o aparato a 10 de Dezembro, uma quinta-feira, no chamado castelo de Cápua, na capital do reino ${ }^{45}$.

Redigido em latim e selado pelo notário e secretário régio aragonês João Olzina, o extenso clausulado abria com um preâmbulo relativo à sintonia entre as embaixadas, ao acordo do rei de Aragão e às assinaturas de ilustres testemunhas, como Fernando, duque da Calábria, João, duque de Cléves, além de representantes das repúblicas de Veneza e de Florença. De seguida, nas disposições nupciais, começava-se por estipular as etapas do casamento: naquela circunstância ficava ajustado por palavras de futuro para no espaço de seis meses se efectivar por palavras de presente, conforme ditavam "os preceitos canónicos e disciplina da religião cristã" ${ }^{46}$, devendo esse acto ser cumprido na corte portuguesa através de uma embaixada imperial mandatada para o efeito. Seguia-se o estabelecimento do dote da noiva, formalmente fixado em 60.000 florins de ouro de câmara segundo o valor da cúria romana, que deveria ser dobrado segundo os usos alemães, traduzindo-se numa pesadíssima soma que o rei de Portugal ficava obrigado a pagar no prazo de quinze meses após a consumação do matrimónio - o dinheiro deveria ser depositado em Bruges, na Flandres, ou em Florença, na Península Itálica, conforme viesse a determinar o imperador, embora se descontassem desse montante 10.000 florins, que se alocavam às despesas da viagem da infanta e do seu séquito ${ }^{47}$. As arras a receber por D. Leonor eram fixadas no mesmo valor do dote, como também era costume no Sacro Império, ficando ao critério de Frederico III o pagamento do complemento pela aquisição da virgindade da nubente, a donationem matutinam (doação da manhã) - assim chamado por normalmente ser paga após a noite de núpcias. Comprometido ficava o rei dos romanos a indicar no espaço de quatro meses o património que asseguraria os réditos anuais de D. Leonor, no valor de 120.000 florins, indispensáveis para sustento da sua casa - Frederico cumpri-lo-ia por carta de 16 de Março de 1451, ao afectar-lhe, no ducado de Carníola, o vice-domínio de Laibach, no ducado de Caríntia, o castelo de Bliburgo e, no ducado de Áustria, a fortaleza de Stuchenstein ${ }^{48}$. Porém, na fase que mediaria até à doação, o imperador colocava à disposição da infanta uma soma igual à dos seus réditos para manutenção da sua honra e estado. Pensando no transporte de D. Leonor, estabelecia-se a sua chegada à Península Itálica até inícios de Novembro, após viagem marítima, devendo desembarcar num porto que Frederico III determinasse, entre Nápoles e Pisa. Consigo, a infanta poderia levar um séquito, masculino e feminino, para seu serviço e acompanhamento, embora se reservasse ao imperador o direito de aprovação do número e qualidade dos membros que seguiriam para o Sacro Império. Por fim, o acordo era meticulosamente encerrado com a descrição do juramento dos procuradores, sob palavra de honra e com as mãos nos Evangelhos, comprometendo assim a dignidade e a alma dos respectivos soberanos ${ }^{49}$.

18 As notícias do acordo terão animado em Portugal o jovem D. Afonso V, mas traziam-lhe responsabilidades para dar sequência à diplomacia. Anfitrião para o casamento por 
palavras de presente, encarregado dos custos da comitiva que transportaria a irmã e, sobretudo, obrigado ao pagamento do dote, o rei português precisava de reunir os estados do reino para cobrir as pesadas despesas que lhe caberiam em breve. Sabemos que convocou Cortes nos finais de Fevereiro de 1451, marcando-as para Santarém, com início dos trabalhos previsto para o dia 30 do mês seguinte ${ }^{50}$. No entanto, devido a alguns atrasos, a assembleia só começou a 3 de Abril. Nas duas semanas em que reuniu, ao contrário do clima de sintonia e concordância plena sugerido por Rui de Pina ${ }^{51}$, sabemos que se fizeram ouvir queixas relacionadas com as exigências financeiras. Os procuradores do concelho de Braga foram rosto desses protestos, argumentando com a difícil situação económica do povo, sujeito a uma pesada carga fiscal que vinha do tempo do infante D. Pedro, o qual, segundo afirmaram ao rei, "lançou mujtos pedidos aos vossos poboos" 52 . Ainda assim, D. Afonso V viu satisfeitas as suas pretensões para o matrimónio da irmã ao serem outorgados dois pedidos e meio a lançar sobre o povo e uma dízima e meia a expensas do clero $^{53}$.

Por esta altura já Frederico III constituíra a embaixada com destino a Portugal, procurando cumprir o prazo estipulado no acordo de Nápoles. Por carta de 14 de Março, dada em Neustadt, o imperador dirige-se ao monarca português, a quem trata agora por "irmão caríssimo", oficializando a creditação dos capelães Tiago de Motz, bacharel em Teologia, e Nicolau Lanckman de Valckenstein ${ }^{54}$, ambos investidos de poderes para que a D. Leonor "desposem como esposa legítima e aceitem como mulher". Com estes representantes segue a solicitação do desembarque da infanta no porto de Siena e a documentação que ratifica o tratado nupcial por parte do imperador, o qual meticulosamente solicita idênticos ofícios da parte de D. Afonso V. Ainda naquele mês, conforme nos relata Lanckman no seu Diário, autêntica narrativa de viagem, deixam Neustadt em direcção ao ducado de Sabóia os dois representantes imperiais, sem com eles seguirem quaisquer outros dignitários ${ }^{55}$. Inicia assim a marcha para Portugal uma embaixada deveras pequena - decerto reveladora do carácter parcimonioso de Frederico III, que astutamente faz justificar a simplicidade da delegação com o estatuto eclesiástico dos seus representantes ${ }^{56}$-, pouco concordante com a condição imperial e muito contrastante com o investimento que D. Afonso V prepara no seu reino.

\section{Com pompa e circunstância: o casamento imperial}

O primeiro casamento de uma princesa portuguesa com um sacro imperador havia que ser celebrado ao mais alto nível. A solenidade das cerimónias, o aparato dos festejos e a opulência dos banquetes assumiam, num mundo do gesto e da palavra, um significado político que não podia ser descurado. Assim parecia apostar D. Afonso V que, segundo Rui de Pina, deixou Santarém e "se foy com sua Corte a Lixboa" em Junho de 1451, por altura do Corpo de Deus, elegendo a maior cidade do reino para acolher os embaixadores imperiais. Como atesta o cronista, pretendia que o "recebimento e entrega [de sua irmã] se fyzesse com grandes e Reaaes festas, pera que fez grandes provimentos e deu muyta pressa"57.

21 Porém, a embaixada de Frederico III tardava em chegar. Após uma viagem, que conhecemos bem, pelo sul de França e pelo norte da Península Ibérica - através de Aragão, Navarra, Castela e Leão -, os capelães foram assaltados na Galiza, chegando com sérias dificuldades a Portugal, por Valença do Minho, disfarçados de peregrinos ${ }^{58}$. Itineraram pelo Porto, Coimbra e Vila Franca, onde foram recebidos "com feestas e muy 
manyfycamente" pelo velho infante D. Henrique, que os terá encaminhado para o Lumiar a 30 de Julho ${ }^{59}$.

22 A entrada dos embaixadores em Lisboa só se fez, de acordo com o Diário de Lanckman, quando D. Afonso $\mathrm{V}$ os mandou chamar ${ }^{60}$. Tudo obedecia a uma cuidada ponderação. Segundo Rui de Pina, era o dia 31 de Julho quando os capelães imperiais pisaram a cidade, sendo recebidos por uma delegação de prelados, nobres e cidadãos e, de imediato, conduzidos ao paço real da alcáçova ${ }^{61}$. Aí chegados, foram levados com toda a solenidade à presença do rei, que os aguardava entre os seus cortesãos, majestaticamente sentado no trono, de ceptro na mão e coroa na cabeça. O monarca apresentava-se, pois, na expressão máxima da sua realeza neste primeiro encontro, uma imponente recepção pormenorizadamente descrita no Diário ${ }^{62}$. Sabemos que nela, como bom anfitrião, D. Afonso $\mathrm{V}$ deu mostras de amizade e magnanimidade ao perguntar pela saúde do imperador, ao interessar-se pelas peripécias da viagem e, por fim, ao ceder aos embaixadores os confortáveis paços dos estaus, no Rossio.

Segundo Lanckman, o casamento foi cuidadosamente precedido de protocolo e formalidade. Logo a 1 de Agosto, o próprio rei começou por apresentar os capelães à rainha, às infantas e aos principais cortesãos, com os quais conviveram. Depois, numa audiência régia que contou com destacados nobres e eclesiásticos, os embaixadores exibiram as credenciais e verbalizaram a vontade do seu senhor em desposar D. Leonor por palavras de presente ${ }^{63}$. A cerimónia terá ocorrido no dia seguinte, de acordo com o Diário ${ }^{64}$, embora Rui de Pina ${ }^{65}$ a date de dia 9, nos paços de S. Cristóvão. A corte marcou presença ao mais alto nível através do casal régio, do infante D. Fernando e das infantas D. Catarina e D. Joana, irmãos da nubente, do velho infante D. Henrique, tio da anterior, a par de muitos prelados, senhores e damas "de grande condiçam" ${ }^{66}$. Lado a lado, D. Leonor e o capelão Tiago Motz, em representação do noivo, escutaram a arenga Adorna thalamum, após o que teve lugar o simbólico ósculo na face e a entrega do anel, seguidos do anúncio da garantia do cumprimento das arras por parte do imperador. Finda a solenidade, soaram as tubas e a infanta "foi por todos declarada e proclamada rainha dos Romanos"

As fontes mostram-nos Lisboa a comemorar amplamente o casamento: no paço real celebrou-se com "suntuosos banquetes", acompanhados de "muytas danças e festas"68; nas igrejas e mosteiros deram-se graças através de cerimónias, procissões e oferendas; nas praças, o povo soltou vivas à imperatriz, "a senhora desposada, Dona Leonor" ${ }^{69}$. Mas a alegria do enlace ia contagiando todo um reino e, aos poucos, revelou-se um bálsamo para as feridas abertas pelo enfrentamento civil, registando-se por esse tempo várias cartas de perdão que o monarca, a rogo da irmã desposada, concedeu a ex-partidários de D. Pedro ${ }^{70}$ - note-se que, em 1451, a memória do infante D. Pedro era ainda assunto "interdito", sendo ainda recente a tensão, no ano anterior, com a embaixada borgonhesa encabeçada pelo Deão de Vergy, Jean Jouffroy, que procurou, sem sucesso, reparar a honra do infante e interceder pelos seus filhos e partidários ${ }^{71}$. Nada melhor do que um magno acontecimento para o rei, senhor da justiça, exibir a virtude da graça.

Durante dois meses aprestou-se afincadamente a viagem de D. Leonor, que deveria ter lugar antes do Inverno. Segundo estudos biográficos da infanta, todo o cuidado material se centrou no enxoval, com um imenso investimento na indumentária, calçado, jóias, serviços de mesa, móveis, códices, livros e jogos ${ }^{72}$. Nessa espera, também por vontade régia, eram dadas a conhecer aos embaixadores várias cidades do reino, com a companhia de D. Leonor ${ }^{73}$. 
No início de Outubro de 1451 aproximava-se a partida da imperatriz. Não sem antes, em sua honra, a Coroa organizar em Lisboa espectaculares e prolongadas festas, segundo Maria Helena Coelho, "ombreando com as mais requintadas da Cristandade" ${ }^{4}$. Entre os dias 13 e 24, desfilou na cidade o escol da hoste real; exibiram-se reis de armas e arautos em representação dos reis europeus; organizaram-se peças teatrais acerca de Frederico III e D. Leonor; justaram, tourearam e caçaram os fidalgos; cantaram e dançaram os populares, cristãos, judeus e mouros, além de selvagens, acompanhados de um elefante, símbolo do exotismo das descobertas. A 24 daquele mês, num paço de madeira, ornamentado com tapeçarias, um faustoso banquete de corte encerrou as festividades, acendendo-se luminárias por toda a Lisboa ${ }^{75}$. No dia seguinte, após missa solene na Sé, celebrada pelo bispo de Ceuta, D. Leonor foi acompanhada em procissão pela família real, senhores e muito povo até ao porto, onde se despediu e embarcou na luxuosa carraca Doria, então mandada vir de Itália ${ }^{76}$.

Acompanhava a imperatriz, além da embaixada alemã, uma impressionante comitiva. D. Afonso $\mathrm{V}$ atribuíra a sua chefia a um primo, o varão e homónimo do duque de Bragança, D. Afonso, que atendendo às suas funções de representação fora elevado por carta régia, havia treze dias, a marquês de Valença - note-se que foi a primeira vez que este título nobiliárquico se concedeu em Portugal ${ }^{77}$. Seguiam-no o bispo de Coimbra D. Luís Coutinho, o vedor da fazenda e conselheiro régio D. Lopo de Almeida, o mordomo-mor Álvaro de Sousa, o regedor da Casa do Cível Pêro Vaz de Melo, entre muitos senhores, oficiais e criados. Já o séquito feminino, encabeçado pela aia de D. Leonor, D. Brites de Meneses, era constituído por três condessas, vinte e quatro aias e muitas serviçais. No total, embarcavam quase 3.000 pessoas, distribuídas por duas carracas, cinco ou seis naus, duas caravelas e oito barcas ${ }^{78}$.

Fosse por falta de vento, como afirma Lanckman, fosse por tardarem as vitualhas e o armamento, segundo Rui de Pina, certo é que a frota só veio a levantar ferro próximo de 20 de Novembro. Ao cabo de uma semana, sabemos que aportou por três dias em Ceuta, talvez por vontade de $\mathrm{D}$. Afonso $\mathrm{V}$ em dar a conhecer a célebre praça norte-africana aos embaixadores de Frederico III. Fazendo-se novamente ao mar, a armada navegou pela costa levantina rumo a Marselha, onde reabasteceu, não sem enfrentar piratas e tempestades. Atracando depois em Grimaud, no leste da Provença, onde se deteve boa parte do mês de Janeiro de 1452 à espera de vento, alcançaria a 1 de Fevereiro o cais de Livorno, um dos principais portos pisanos ${ }^{79}$. 
Figura 2 - De Lisboa a Livorno: a atribulada viagem marítima de D. Leonor (Novembro de 1451 a Fevereiro de 1452)

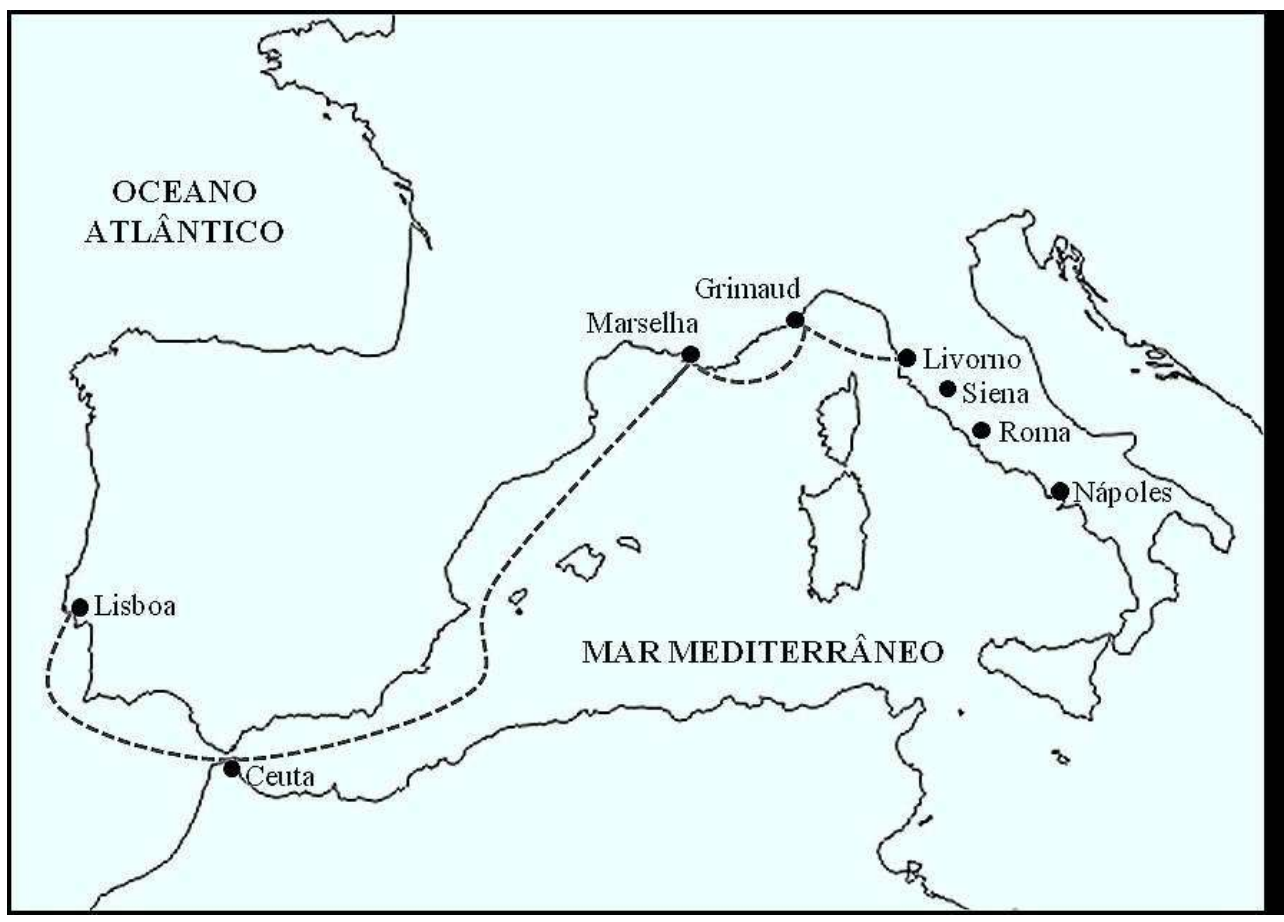

Fonte: Infografia do autor sobre Mapa "Europa Ocidental (Costas Branco)", extraído do site: www.dmaps.com

Uma vez que Livorno não era o ancoradouro acordado com Frederico III, ninguém desembarcou. Porém, logo o mau tempo levou a que muitos adoecessem a bordo, vindo a terra Nicolau Lanckman informar o imperador, então em Siena, o qual pronto consentiu o desembarque da comitiva de D. Leonor e enviou uma numerosa delegação de 500 senhores para a acompanhar a Pisa, onde a princesa entretanto chegaria para se recompor da viagem ${ }^{80}$.

Entre 19 e 21 de Fevereiro, D. Leonor partiu com o séquito luso-imperial em direcção a Siena para se reunir ao esposo. Na cidade preparava-se meticulosamente o encontro, cujo ritual ficaria descrito inclusivamente na primeira de um conjunto de cartas enviadas por D. Lopo de Almeida a D. Afonso $\mathrm{V}^{81}$, que tudo fazia questão de acompanhar à distância, além de ter sido imortalizado pela pintura de Pinturicchio ${ }^{82}$, que se conserva na Catedral de Siena. Temos notícia de que D. Leonor chegou aos arredores dessa cidade no dia 24, sendo recebida pelo próprio rei da Boémia e da Hungria, Ladislau, e pelo irmão do imperador e duque da Áustria, Alberto, juntamente com muitos nobres do Sacro Império, senhores das repúblicas de Veneza, Bolonha e Florença e cardeais legados da Santa Sé. Cumprindo a hierarquia, acompanharam a imperatriz até às portas da urbe, de onde um grupo de cidadãos com um pálio, no qual figuravam as armas portuguesas e imperiais, a transportaram até ao Rei dos Romanos, que aguardava no interior. Avistando-se, Frederico III e D. Leonor apearam-se das montadas e, com toda a cortesia, trocaram-se saudações. Apregoado um solene discurso, o arcebispo da cidade, Eneas Sílvio Piccolomini (futuro Papa Pio II), deu a cruz a beijar, após o que o casal se dirigiu à sé, onde rezou por instantes. As fontes referem cuidadosamente que D. Leonor, salvo um momento em que folgou com o esposo no dia após o encontro, estanciou num paço "soo, sem o Emperador" 
${ }^{83}$. Faltava ainda "fazer suas vodas"84, que se perspectivavam na celestíssima Roma, onde o primeiro imperador dos Habsburgo, num projecto de legitimação plena, esperava também ser coroado pelas mãos do Sumo Pontífice.

31 Igualmente separados viajaram os esposos nos dias seguintes em direcção à Cidade Santa, a cujas portas se reuniram a 8 de Março para, como era tradição, entrarem no dia seguinte com todo o aparato de indumentária e de música. À porta da igreja de S. Pedro, o Papa Nicolau V aguardava Frederico III e D. Leonor, que ingressaram no templo ao som de órgão e de cânticos, para depois orarem no altar-mor e se retirarem para as respectivas pousadas - note-se que a honra concedida nesta e nas seguintes cerimónias correspondia, da parte do Papa, a uma retribuição de favor ao imperador que submetera o cismático Félix V à sua autoridade havia três anos ${ }^{85}$.

Chegado o dia 16 de Março, quinta-feira, Frederico III e D. Leonor reunir-se-iam de novo em S. Pedro, onde Nicolau V os esperava para, em missa solene, selar o enlace, no dizer de Rui de Pina, com "as benções que a Santa Ygreja aos casamentos ordena" ${ }^{86}$. Sabemos, por outra carta de D. Lopo de Almeida ${ }^{87}$, que a cerimónia foi antecedida de um incidente protocolar levantado pela imperatriz, que, sob influência da comitiva portuguesa, recusou ser acompanhada até à igreja pelos dois duques enviados por Frederico, exigindo alguém com sangue real, como o rei da Hungria ou o duque da Áustria, parentes do imperador. Perante a intransigência do Rei dos Romanos, acabaria por ceder, mas sem esquecer. Iniciada a eucaristia, Frederico III e D. Leonor, de joelhos, começaram por beijar o pé e as mãos do Papa em sinal de obediência. Depois, o Pontífice benzeu os anéis, colocou-os nos dedos dos esposos e, após ouvir o assentimento de que casavam de livre vontade, mandou que se beijassem nas faces, posto o que os abençoou. Segundo D. Lopo de Almeida, o ofício terminaria jubilosamente ao som de "duas estantes de cantores", que "cantavam a

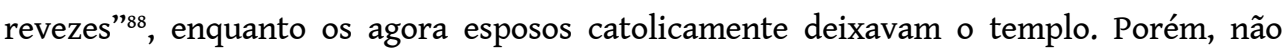
houve festejos nem consumação pois, recordam as fontes, era Quaresma, e os cônjuges "assy tomaram por devaçam"

Agora Frederico III e D. Leonor preparavam-se para um derradeiro regresso à igreja de S. Pedro, negociada que fora a cerimónia de sagração e coroação imperial, a última que teve lugar em Roma sob a autoridade papal. A 19 de Março, Domingo, Nicolau V recebeu primeiro o imperador, a quem ajoelhou, e depois a imperatriz, ungida nas espáduas e no braço direito. Iniciada a Missa, o Papa, ao Evangelho, coroou o casal, entregando ao rei dos romanos, à semelhança de Carlos Magno no Natal de 800, as insígnias da sua majestade: a espada, o ceptro e o globo. Por último, o casal imperial comungou pela mão do Santo Padre e, finalizada a cerimónia com um majestoso Te Deum, desceu à urbe com as coroas na cabeça ${ }^{90}$.

34 A próxima etapa de Frederico III e D. Leonor seria o reino de Nápoles, onde os aguardava para as núpcias D. Afonso V de Aragão, procurando explorar a aliança daquela união. Saída de Roma a 24 de Março, com dois dias de diferença do marido, a imperatriz terá alcançado no fim do mês a capital napolitana, a meia-légua da qual veio esperá-la com todas as honras o monarca seu tio. 0 rei não olhou a despesas para, em plena quadra quaresmal, festejar a presença dos esposos com banquetes, danças, peças teatrais, jogos de canas, caçadas e justas, além de desfiles de cavaleiros e donzelas. Por fim, no Domingo de Pascoela, passado o período de interdito, o imperador anunciou o desejo de consumar o casamento ${ }^{91}$.

A respeito do último rito matrimonial, enquanto Lanckman, eclesiástico, se revela discreto $^{92}$, D. Lopo de Almeida, em carta para D. Afonso V, não se poupa em detalhes. 
Sabemos que na noite de 16 de Abril, no castelo de Cápua, a jovem D. Leonor, de 17 anos, foi levada ao quarto nupcial e deitada ao lado do esposo, de 36 anos, com o qual publicamente, conforme "usança d'Alemanha" ${ }^{93}$, trocou um beijo. Logo a imperatriz se dirigiu para a sua câmara, aguardando que a fossem buscar para a real efectivação do acto. Eis que quando surgiram dois condes para a acompanhar ao leito de núpcias se recusou a ser conduzida - como que se desforrando da idêntica afronta de Roma -, dando conta de que, mesmo nos contextos mais íntimos do enlace, exigia uma honra superior. As embaixadas sucederam-se por cinco ou seis vezes, sem lograrem dobrar a vontade de D. Leonor. Por fim, Frederico III veio rogar a sua presença, acedendo a imperatriz, levada pela mais alta dignidade. Consumado o acto, a já esposa carnal do Rex Romanorum recebeu a renda de câmara prevista na manhã seguinte ${ }^{94}$.

O imperador partiria para Roma e D. Leonor, em Nápoles até 24 de Abril, reunir-se-lhe-ia ao cabo de algumas semanas em Veneza para, cruzado o Mar Adriático, chegarem a Neustadt a 19 de Junho. A imperatriz começava então a sua vida no novo reino, onde ao longo de quinze anos testemunharia a realidade da guerra e da revolta até falecer, a 3 de Setembro de 1467, aos 33 anos, 26 antes do marido. Com ele, com quem se diz não ter sido feliz pelas diferenças de costumes e de carácter ${ }^{95}$, cumpriu o essencial do matrimónio ao assegurar a sucessão em Maximiliano - o único dos cinco filhos, a par de Cunegundes, a atingir a idade adulta - e, desse modo, o estabelecimento dos Habsburgo como dinastia imperial. À monarquia portuguesa, que ao seu casamento somou o da infanta D. Joana com o rei D. Henrique IV de Castela em 1455, num claro momento de internacionalização, o matrimónio de D. Leonor abriu um novo ciclo de contactos com o Sacro Império Romano-Germânico ${ }^{96}$.

O enlace de D. Leonor e Frederico III propiciou desde logo o lançamento das primeiras sementes para a intensificação de relações entre os seus reinos, como mostra a acção de D. Lopo de Almeida a partir da comitiva matrimonial para fomentar o comércio salífero, conforme mandatado por D. Afonso $\mathrm{V}^{97}$. De facto, a aproximação das coroas cedo conduziu a um incremento económico, de tal modo que, por volta de 1455, como estudou Oliveira Marques, se estabeleceu em Lisboa uma colónia alemã ${ }^{98}$. Em parte pela existência dessa comunidade, que unia interesses de ambos os reinos, a protecção a súbditos imperiais propiciou uma circulação social que, na viragem para o século XVI, trouxe a Portugal o cosmógrafo Martin Behaim, o cartógrafo Jerónimo Müzner ou o impressor Valentim Fernandes ${ }^{99}$. Na base, as relações políticas entre as monarquias, unidas por laços familiares, revelar-se-iam em momentos cruciais, como foi o caso da assinatura da aliança militar em 1493 entre D. João II e Maximiliano I, tão útil no contexto das negociações do Tratado de Tordesilhas (1494), ou quando em 1525 D. João III e Carlos V, incompatibilizado com meia Europa, selaram um matrimónio imperial envolvendo a infanta D. Isabel, entrelaçando assim com novos nós as relações entre Portugal e o Sacro Império no advento da modernidade ${ }^{100}$.

\section{Conclusão}

O casamento de D. Leonor e Frederico III (1451-1452) constitui, sem dúvida, um acontecimento importante para compreender as relações luso-imperais e, num sentido mais lato, as complexas teias diplomáticas que as unidades políticas urdiam na Europa dos finais da Idade Média. Como tal, apesar de profusamente retratado ao nível das fontes e de abordado por sucessivas gerações de investigadores, o enlace régio despertou a nossa 
atenção para elaborar um estudo que o perspectivasse na óptica das relações internacionais, uma área que, como dissemos, se tem vindo a desenvolver na historiografia nacional nas últimas três décadas.

Num primeiro ponto, enquadrados por uma Cristandade em definição de fronteiras, atestámos a importância dos casamentos régios na estratégia diplomática promovida pelas cabeças coroadas, que entendiam a união das linhagens como a melhor forma de selar alianças. Foi disso exemplo a dinastia de Avis durante o seu processo de legitimação, bem patente na primeira metade do século XV, ao capitalizar a descendência do reifundador, D. João I, para se ligar às casas de Inglaterra, Aragão e Borgonha, assim como a de seu sucessor, D. Duarte, amplamente negociada durante a regência do infante D. Pedro. Seria, no entanto, no início da governação de $\mathrm{D}$. Afonso $\mathrm{V}$ que se cruzariam os destinos de Portugal e do distante Sacro Império, sob a mediação do rei de Aragão, tio e homónimo do monarca português, que demonstrou o (longo) alcance das ligações genealógicas nas relações internacionais ao promover o casamento de Frederico III com uma infanta lusa para, em última análise, garantir o apoio alemão na segurança das suas possessões italianas. Neste projecto matrimonial convergiriam os interesses políticos por parte do rei dos romanos, carente de descendência para firmar a dinastia Habsburgo no trono imperial, e de D. Afonso V que, no contexto da crise de Alfarrobeira (1449), encontraria uma oportunidade de ouro para prestigiar a sua realeza ligando-a à mais alta esfera (temporal) da Cristandade, dando assim sequência ao interesse manifestado pelo imperador pela mais velha das suas irmãs, D. Leonor.

40 Foi justamente sobre o processo negocial luso-alemão que, num segundo momento, nos debruçámos, permitindo-nos observar o desenvolvimento da prática da diplomacia por esse tempo, da organização aos meios, passando pela etiqueta e pelos formalismos, sintoma dos progressos da afirmação régia. Entre Portugal e o Sacro Império, sobretudo ao longo de 1450, assistimos à cuidada preparação de embaixadas, sendo notória a ponderação dos soberanos ao fazerem-se representar, para além de nobres e eclesiásticos, por burocratas e legistas, num período em que o Direito se consolidava no funcionamento institucional das monarquias. Corolário desse empenho foram as negociações que tiveram lugar em Nápoles entre Outubro e Dezembro daquele ano, sob o patrocínio do rei de Aragão, que resultaram no complexo articulado jurídico das capitulações matrimoniais, as quais estabeleceram os contornos do casamento imperial, desde logo bastante oneroso para a coroa portuguesa, conforme comprovaram as cortes reunidas em Santarém em Abril de 1451.

41 No terceiro e último ponto pudemos analisar as etapas do casamento luso-imperial, pleno de significado institucional e religioso, caracterizado pela magnificência das cerimónias, desde o enlace por palavras de presente, em Agosto de 1451, à sua própria consumação, em Abril do ano seguinte. Em Portugal, entre o Verão e o Outono de 1451, o investimento da Coroa revelou-se um verdadeiro barómetro que atestou a importância do casamento nas relações internacionais, bem patente na majestática recepção régia por $\mathrm{D}$. Afonso $\mathrm{V}$ aos embaixadores alemães, no formalíssimo casamento por procuração, nos longos e exuberantes festejos - espirituais e profanos - em que toda a sociedade foi chamada a tomar parte, no aparato da frota que se aprestou em Lisboa e na grandeza - quantitativa e qualitativa - da comitiva que acompanharia a infanta. Na sequência de uma agitada viagem que decorreu entre Novembro de 1451 e Fevereiro de 1452, acompanhámos o multifacetado percurso de D. Leonor em terras italianas, desde o ritual do encontro com o noivo, em Siena (Figura 3) ${ }^{101}$, à efectivação carnal do matrimónio, em Nápoles, passando 
pela bênção nupcial e pela coroação imperial, em Roma, no primeiríssimo templo e pelas mãos do principal prelado da Cristandade. Destaque-se como estas notícias nos chegaram essencialmente pela documentação elaborada no seio da comitiva portuguesa que, para além de acompanhar a imperatriz e de representar o seu reino de origem, procurava a toda a hora informar $\mathrm{D}$. Afonso $\mathrm{V}$ dos seus passos, num verdadeiro serviço de informações diplomático.

Do casamento entre Frederico III e D. Leonor resultou claramente uma inflexão nas relações de duas monarquias, de que são exemplo o incremento económico, a circulação social e uma aproximação política que, no início do século XVI, se renovaria com um novo matrimonial luso-imperial. Numa perspectiva portuguesa, muito em particular, D. Afonso $\mathrm{V}$ conseguiu com o enlace imperial legitimar plenamente a dinastia de Avis, abrindo caminho sob o seu governo para um ciclo em que Portugal, nas palavras de Saul António Gomes, "viu intensificarem-se como nunca as relações diplomáticas na Cristandade" ${ }^{102}$.

Figura 3 - 0 encontro de Siena entre Frederico III e D. Leonor

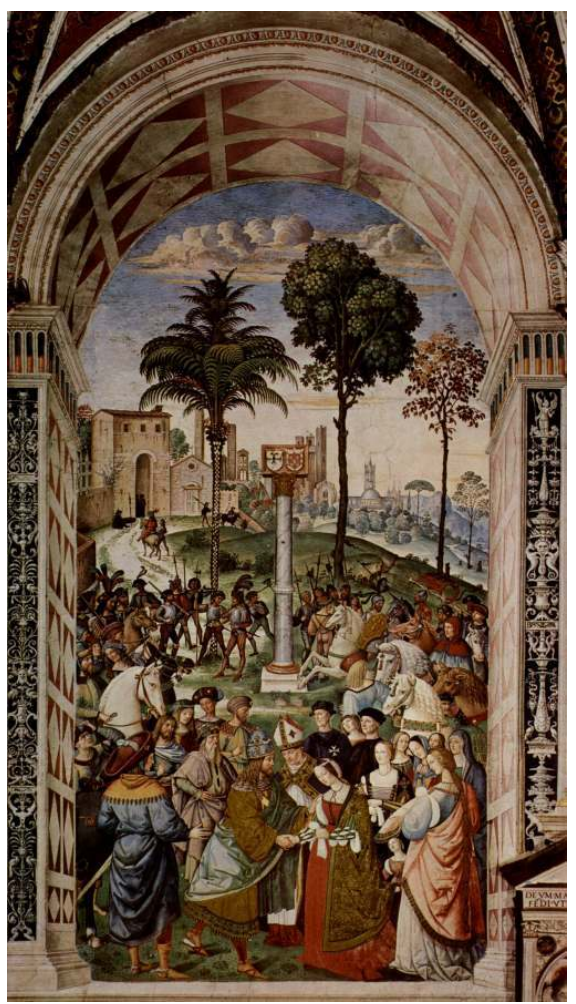

Fonte: Bernardino di Betti (1454-1513), Enea Silvio, vescovo di Siena, presenta Eleonora d'Aragona all'imperatore Federico III (1502-1507), fresco. Libreria Piccolomini, Siena, Duomo (domínio público).

\section{BIBLIOGRAFIA}

Fontes 
ALMEIDA, Lopo de - Cartas de Itália. Ed. lit. Rodrigues Lapa. Lisboa: Imprensa Nacional - Casa da Moeda, 1935.

Monumenta Henricina. Dir., Org. e anotação crítica de António Joaquim Dias Dinis. Vol. 9 (1445-1448); Vol. 10 (1449-1451); Vol. 11 (1451-1454). Coimbra: Comissão Executiva das Comemorações do V Centenário da Morte do Infante D. Henrique, 1968-1969.

NOGUEIRA, Pedro Álvares - Livro das Vidas dos Bispos da Sé de Coimbra. Coord. Manuel Augusto Rodrigues. Transc. Maria Teresa Nobre Veloso. Coimbra: Arquivo da Universidade de Coimbra, 2003.

PINA, Rui de - Crónicas de Rui de Pina. Introd. e rev. de M. Lopes de Almeida. Porto: Lello \& Irmão, 1977.

Princesas de Portugal: contratos matrimoniais dos séculos XV e XVI. Trad. Aires A. Nascimento. Lisboa: Cosmos, 1992.

SANTARÉM, Visconde de - Quadro elementar das relações políticas e diplomáticas de Portugal com as diversas potências do Mundo desde o princípio da Monarchia Portugueza até aos nossos dias ordenado e composto pelo Visconde de Santarém. Vol. 1. Pariz: J. P. Aillaud, 1842.

Trellado do liuro vermelho de tempo Dell Rey Dom afo[n]so o quinto. [1471]. Fonte manuscrita disponível em: https://bdigital.sib.uc.pt/bg1/UCBG-Cofre-21/UCBG-Cofre-21_item1/index.html

VALCKENSTEIN, Nicolau Lanckman de - Leonor de Portugal, imperatriz da Alemanha: Diário de viagem do embaixador Nicolau Lanckman de Valckenstein. Trad. Aires A. Nascimento. Lisboa: Cosmos, 1992.

Estudos

ARAÚJO, Julieta - Portugal e Castela na Idade Média. Lisboa: Edições Colibri, 2009.

ALMEIDA, Adriana R. de - The marriage of Leonor of Portugal and Emperor Frederick III: a case-study of politics and affection in the mid-fifteenth century. Londres: Royal Holloway, 2007. Dissertação de Mestrado (não publicada).

ALMEIDA, Adriana R. de - "Perspectiva sobre a história das emoções. O casamento de D. Leonor de Portugal com o imperador Frederico III". in RODRIGUES, Ana Maria; SILVA, Manuela Santos; Faria, Ana Leal de (Coords.) - Casamentos da Família Real Portuguesa: diplomacia e cerimonial. Vol. 1. Lisboa: Círculo de Leitores, 2017, pp. 253-287.

ASKINS, Arthur L-F.; SCHAFFER, Martha E.; SHARRER, Harvey L. - "A New Set of Cartas de Itália to Afonso V of Portugal from Lopo de Almeida and Luís Goncalves Malafaia”. Romance Philology 57 (2003), pp. 71-88.

BARRADAS, Alexandra Leal - "D. Afonso, 4. Conde de Ourém: viagens, cultura visual e formação de um gosto". Medievalista on line 2 (2006).

BASKINS, Cristelle - "The Triumph of Marriage: Frederick III and Leonora of Portugal, 1452". in The Triumph of Marriage: Painted Casonni of the Renaissance. Boston: Isabella Stewart Gardner Museum, 2009, pp. 47-65.

COELHO, Maria Helena da Cruz - "A política matrimonial da dinastia de Avis: Leonor e Frederico III da Alemanha”. Revista Portuguesa de História 36 (1) (2002-2003), pp. 41-70.

COELHO, Maria Helena da Cruz - D. João I, o que re-colheu Boa Memória. Lisboa: Círculo de Leitores, 2005.

COELHO, Maria Helena da Cruz - D. Leonor de Portugal: a imperatriz, 1434-1467. Vila do Conde: QuidNovi, 2011. 
CORDEIRO, Luciano - Portugueses fora de Portugal. Uma sobrinha do Infante, Imperatriz da Allemanha e Rainha da Hungria. Lisboa: Imprensa Nacional - Casa da Moeda, 1894.

COSTA, António Martins - A Batalha de Toro e as relações entre Portugal e Castela: dimensões políticas e militares. Lisboa: Faculdade de Letras da Universidade de Lisboa, 2011. Dissertação de Mestrado.

Dicionário de História de Portugal. Dir. Joel Serrão. 9 vols. Lisboa: Livraria Figueirinhas, 2000.

DUARTE, Luís Miguel - D. Duarte: requiem por um rei triste. Lisboa: Círculo de Leitores, 2005.

FREITAS, Judite Antonieta Gonçalves de - “Teemos por bem e mandamos": a burocracia régia e os seus oficiais em meados de Quatrocentos (1439-1460). 2 vol. Cascais: Patrimonia, 2001.

GOMES, Saul António - D. Afonso V, o Africano. Lisboa: Círculo de Leitores, 2006.

HANREICH, Antonia - “D. Leonor de Portugal, esposa do imperador Frederico III (1436-1467)”. in SCHEIDL, Ludwig; CAETANA, José A. Palma (Dirs.) - Relações entre a Áustria e Portugal. Testemunhos históricos e culturais. Coimbra: Livraria Almedina, 1985, pp. 3-27.

HERBERS, Klaus - "El viaje a Portugal de los embajadores de Federico III en el relato de Lanckmann y de otros cronistas". Anuario de Estudios Medievales 32 (1) (2002), pp. 183-198.

HERNANDO, Máximo Diago - El Imperio en la Europa Medieval. Madrid: Arco Libro, 1996.

LE GOFF, Jacques - A civilização do ocidente medieval. Vol 1. Lisboa: Estampa, 1994.

LIMA, Henrique de Campos Ferreira - D. Leonor de Portugal, filha d'el rei D. Duarte, imperatriz da Alemanha: notas iconográficas. Porto: s. n, 1921.

LOPES, Marília dos Santos - "Relações de Portugal com a Alemanha". in ALBUQUERQUE, Luís (Dir.) - Dicionário de História dos Descobrimentos Portugueses. Vol. 1. Lisboa: Caminho, 1994, pp. 44-48.

LOPES, Marília dos Santos - “Ao serviço do Império: a nobilitação de estrangeiros na corte joanina e manuelina". in Pequena Nobreza nos Impérios Ibéricos de Antigo Regime. Lisboa: Instituto de Investigação Científica Tropical, 2012, pp. 1-8.

MACEDO, Jorge Borges de - História Diplomática Portuguesa: constantes e linhas de força. Vol. 1. Lisboa: Tribuna da História, 2006.

MARQUES, António Henrique de Oliveira - Hansa e Portugal na Idade Média. Lisboa: Presença, 1993.

MARQUES, António Henrique de Oliveira - ; SERRÃO, Joel (Dirs.) - Nova História de Portugal. Vol. 4. Lisboa: Presença, 1987.

MENDONÇA, Manuela - As relações externas de Portugal nos finais da Idade Média. Lisboa: Colibri, 1994.

MONTEIRO, Nuno; RAMOS, Rui; SOUSA, Bernardo Vasconcelos e - História de Portugal. Lisboa: A Esfera dos Livros, 2010.

MORENO, Humberto Baquero - A Batalha e Alfarrobeira: antecedentes e significado histórico. Vol. 1. Coimbra: Universidade de Coimbra, 1979.

MORENO, Humberto Baquero - "O papel da diplomacia portuguesa no Tratado de Tordesilhas". História - Revista da Faculdade de Letras da Universidade do Porto 12 (1995), pp. 135-150.

MORENO, Humberto Baquero - "Portugal: do Mediterrâneo ao Atlântico, no século XV”. História Revista da Faculdade de Letras da Universidade do Porto 13 (1996), pp. 187-203. 
OLIVEIRA, António Resende de - “'Mais de pedras que de livros': D. Afonso, 4.ํ Conde de Ourém, e a cultura nobiliárquica do seu tempo". in ANDRÉ, Carlos Ascenso (Coord.) - D. Afonso, 4. ․ Conde de Ourém e a sua época. Ourém: Câmara Municipal de Ourém, 2004, pp. 293-310.

PAVIOT, Jacques - Portugal et Bourgogne au XVe siècle (1384-1482). Lisboa: Comissão Nacional para as Comemorações dos Descobrimentos Portugueses; Paris; Centre Culturel Calouste Gulbenkian, 1995.

PÉQUIGNOT, Stephane - "Les diplomaties occidentales, XIIIe-XVe siècles". Les relations diplomatiques au Moyen Âge. Formes et enjeux. Actes du XLIe Congrès de la SHMESP (Lyon, 3-6 juin 2010). Paris: Publications de la Sorbonne (Histoire ancienne et médiévale), 2011, pp. 47-66.

PÉQUIGNOT, Stephane - ; et al. - Negociar en la Edad Media / Négocier au Moyen Age. Barcelone: CSIC (Anejos del Anuario de Estudios Medievales, 61), 2005.

RAMOS, Manuel - "Os membros da Geração de Avis: amizades, inimizades e falta de exemplaridade”. in Symbolon I: Amor e Amizade. Porto: Universidade do Porto, 2009, pp. 91-114.

RAU, Virgínia - "Relações diplomáticas de Portugal durante o reinado de D. Afonso V". in Estudos de História Medieval. Lisboa: Editorial Presença, 1986, pp. 66-80.

RODRIGUES, Ana Maria S. A. - "For the honor of her lineage and body: The dowers and dowries of some late medieval queens of Portugal". E-Journal of Portuguese History 1 (5) (2007), pp. 1-13.

RODRIGUES, Ana Maria S. A. - As tristes rainhas. Leonor de Aragão. Isabel de Coimbra. Lisboa: Círculo de Leitores, 2012.

RODRIGUES, Paula - "A teia de Avis. Estratégias matrimoniais para a legitimação de uma dinastia. As primeiras gerações (1387-1430)”. in RODRIGUES, Ana Maria S. A.; SILVA, Manuela Santos; FARIA, Ana Leal de (Coords.) - Casamentos da Família Real Portuguesa. Vol. 1. Lisboa: Círculo de Leitores, 2017, pp. 35-56.

SILVA, Manuela Santos - "O casamento de D. Beatriz (filha natural de D. João I) com Thomas Fitzalan (Conde de Arundel): paradigma documental da negociação de uma aliança”. in FARIA, Ana Leal de; BRAGA, Isabel Drumond (Coords.) - Problematizar a História: estudos de História Moderna em homenagem a Maria do Rosário Themudo Barata. Casal de Cambra: Caleidoscópio, 2007, pp. 77-92.

SOUSA, Armindo de - As Cortes medievais portuguesas (1385-1490). Vol. 1. Porto: Instituto Nacional de Investigação Científica, 1990.

SOUSA, Bernardo Vasconcelos e; PIZARRO, José Augusto de Sotto Mayor - "O casamento". in MATTOSO, José (Dir), SOUSA, Bernardo Vasconcelos e (Coord.) - História da Vida Privada em Portugal. A Idade Média. Lisboa: Círculo de Leitores e Temas e Debates, 2010.

STRASEN, E. A.; GÂNDARA, Alfredo - "Uma portuguesa imperatriz da Alemanha". in Oito séculos de história luso-alemã. Lisboa: Instituto Ibero-Americano de Berlim, 1944, pp. 69-90.

VITERBO, Sousa - D. Leonor de Portugal, imperatriz da Alemanha: notas documentadas para o estudo biografico d'esta princesa e para a historia das relações da Corte de Portugal com a Casa da Austria. Lisboa: Of. Tip. Calçada do Cabra 7, 1910. 


\section{NOTAS}

1. SOUSA, Bernardo Vasconcelos e; PIZARRO, José Augusto de Sotto Mayor - "O casamento". in MATTOSO, José (Dir.), SOUSA, Bernardo Vasconcelos e (Coord.) - História da Vida Privada em Portugal. A Idade Média. Lisboa: Círculo de Leitores e Temas e Debates, 2010, p. 127.

2. SANTARÉM, Visconde de - Quadro elementar das relações políticas e diplomáticas de Portugal com as diversas potências do Mundo desde o princípio da Monarchia Portugueza até aos nossos dias ordenado e composto pelo Visconde de Santarém. Vol. 1. Pariz: J. P. Aillaud, 1842.

3. VITERBO, Sousa - D. Leonor de Portugal, imperatriz da Alemanha: notas documentadas para o estudo biografico d'esta princesa e para a historia das relações da Corte de Portugal com a Casa da Austria. Lisboa: Of. Tip. Calçada do Cabra 7, 1910.

4. STRASEN, E. A.; GÂNDARA, Alfredo - "Uma portuguesa imperatriz da Alemanha". in Oito séculos de história luso-alemã. Lisboa: Instituto Ibero-Americano de Berlim, 1944, pp. 69-90.

5. HANREICH, Antonia - "D. Leonor de Portugal, esposa do imperador Frederico III (1436-1467)". in SCHEIDL, Ludwig; CAETANA, José A. Palma (Dirs.) - Relações entre a Áustria e Portugal. Testemunhos históricos e culturais. Coimbra: Livraria Almedina, 1985, pp. 3-27.

6. COELHO, Maria Helena da Cruz - "A política matrimonial da dinastia de Avis: Leonor e Frederico III da Alemanha”. Revista Portuguesa de História 36 (1) (2002-2003), pp. 41-70.

7. ALMEIDA, Adriana R. de - The marriage of Leonor of Portugal and Emperor Frederick III: a case-study of politics and affection in the mid-fifteenth century. Londres: Royal Holloway, 2007. Dissertação de Mestrado (não publicada). Mais recentemente, da mesma autora, foi publicado o capítulo: "Perspectiva sobre a história das emoções. O casamento de D. Leonor de Portugal com o imperador Frederico III". in RODRIGUES, Ana Maria; SILVA, Manuela Santos; FARIA, Ana Leal de (Coords.) - Casamentos da Familia Real Portuguesa: diplomacia e cerimonial. Vol. 1. Lisboa: Círculo de Leitores, 2017, pp. 253-287.

8. BRANCO, Maria João, FARELO, Mário - "Diplomatic Relations: Portugal and the Others". in MATTOSO, José (Dir.); ROSA, Maria de Lurdes; SOUSA, Bernardo Vasconcelos e; BRANCO, Maria João (Coord.) - The historiography of medieval Portugal, c. 1950-2010. Lisboa: Instituto de Estudos Medievais, 2011, pp. 251-259.

9. MACEDO, Jorge Borges de - História Diplomática Portuguesa: constantes e linhas de força. Vol. 1. Lisboa: Tribuna da História, 2006, pp. 67-72.

10. LE GOFF, Jacques - A Civilização do Ocidente Medieval. Vol. 1. Lisboa: Editorial Estampa, 1983, pp. 141-145.

11. RODRIGUES, Ana Maria S. A. - "For the honor of her lineage and body: The dowers and dowries of some late medieval queens of Portugal". E-Journal of Portuguese History 1 (5) (2007), pp. $1-2$.

12. O esforço de legitimação da dinastia de Avis, instituída ao arrepio da legítima sucessão de D. Fernando I, passou nas suas primeiras décadas, concomitantemente aos projectos matrimoniais, por uma política de propaganda régia patente na arquitectura, na escultura, na cronística e na literatura, que decorria sob um centralismo governativo da Coroa, de cuja afirmação não se pode separar ainda o acontecimento guerreiro da tomada da islâmica Ceuta, em África, no ano de 1415. Veja-se COELHO, Maria Helena da Cruz - D. João I, o que re-colheu Boa Memória. Lisboa: Círculo de Leitores, 2005.

13. Viúva de Sir Thomas Fitzalen em 1415, D. Brites viria a contrair um segundo matrimónio em Inglaterra, em 1432, ao desposar John Holland, conde de Huntingdon. Veja-se SILVA, Manuela Santos - "O casamento de D. Beatriz (filha natural de D. João I) com Thomas Fitzalan (Conde de Arundel): paradigma documental da negociação de uma aliança". in FARIA, Ana Leal de; BRAGA, 
Isabel Drumond (Coords.) - Problematizar a História: estudos de História Moderna em homenagem a Maria do Rosário Themudo Barata. Casal de Cambra: Caleidoscópio, 2007, pp. 77-92.

14. COSTA, António Martins - A Batalha de Toro e as relações entre Portugal e Castela: dimensões políticas e militares. Lisboa: Faculdade de Letras da Universidade de Lisboa, 2011. Dissertação de Mestrado, pp. 39-40; MARQUES, A. H. de Oliveira; SERRÃO, Joel (Dirs.) Nova História de Portugal. Vol. 4. Lisboa: Presença, 1987, pp. 530-548; RODRIGUES, Paula "A teia de Avis. Estratégias matrimoniais para a legitimação de uma dinastia. As primeiras gerações (1387-1430)”. in RODRIGUES, Ana Maria S. A.; SILVA, Manuela Santos; FARIA, Ana Leal de (Coords.) - Casamentos da Familia Real Portuguesa. Vol. 1. Lisboa: Círculo de Leitores, 2017, pp. 35-56.

15. DUARTE, Luís Miguel - D. Duarte: requiem por um rei triste. Lisboa: Círculo de Leitores, 2005, pp. 253-256.

16. ARAÚJO, Julieta - Portugal e Castela na Idade Média. Lisboa: Edições Colibri, 2009, pp. 153-195; MORENO, Humberto Baquero - A Batalha e Alfarrobeira: antecedentes e significado histórico. Coimbra: Universidade de Coimbra, 1979, pp. 191-239.

17. CORDEIRO, Luciano - Portugueses fora de Portugal. Uma sobrinha do Infante, Imperatriz da Allemanha e Rainha da Hungria. Lisboa: Imprensa Nacional - Casa da Moeda, 1894, p. 38.

18. Note-se que D. Pedro gozaria de uma certa proximidade junto dos descendentes de Segismundo III, uma vez que, após a conquista de Ceuta, servira o imperador na luta contra os turcos otomanos. Fora justamente nesse contexto que Segismundo o fizera senhor da marca de Treviso em 1418. Veja-se MARQUES, A. H. de Oliveira; SERRÃO, Joel (Dirs.) - Nova História de Portugal. Lisboa: Presença, 1987, vol. 4, p. 546.

19. MORENO, Humberto Baquero - A Batalha de Alfarrobeira, vol. 1, p. 323.

20. PINA, Rui de - “Crónica de D. Afonso V”. in Crónicas de Rui de Pina. Introd. e rev. de M. Lopes de Almeida. Porto: Lello \& Irmão, 1977, cap. LXXVIII-CXXII, pp. 698-749.

21. Monumenta Henricina. Dir, org. e anotação crítica de António Joaquim Dias Dinis. Vol. 9 (1445-1448). Coimbra: Comissão Executiva das Comemorações do V Centenário da Morte do Infante D. Henrique, 1968, docs. 203-206.

22. MARQUES, A. H. de Oliveira; SERRÃO, Joel (Dirs.) - Nova História de Portugal. Lisboa: Presença, 1987, vol. 4, pp. 330-332.

23. DIAGO HARNANDO, Máximo - El Imperio de la Europa Medieval. Madrid: Arco Libros, 1996, p. 57. 24. Segundo Antonia Hanreich, em 1448 Frederico III somava já três tentativas matrimoniais abortadas, uma delas visando uma princesa francesa, outra a filha do anti-papa Félix V e, por fim, a viúva do antigo imperador Alberto II, Isabel, mãe do jovem Ladislau do Luxemburgo, com quem D. Isabel da Borgonha e o infante D. Pedro tinham procurado casar a infanta D. Joana. Veja-se HANREICH, Antonia - “D. Leonor de Portugal”, p. 5.

25. ALMEIDA, Adriana R. de - "Perspectiva sobre a história das emoções", p. 261; STRASEN, E. A., GÂNDARA, Alfredo - "Uma portuguesa imperatriz da Alemanha", p. 69.

26. SOUSA, Bernardo Vasconcelos e - "O início da expansão ultramarina". in MONTEIRO, Nuno; RAMOS, Rui; SOUSA, Bernardo Vasconcelos e - História de Portugal. Lisboa: A Esfera dos Livros, 2010, pp. 183-196.

27. A carta do rei de Aragão e Nápoles a que nos referimos, destinada à infanta D. Leonor, data de 18 de Janeiro de 1451, já numa fase mais adiantada do seu processo matrimonial. Veja-se Monumenta Henricina. Vol. 11 (1451-1454), doc. 1.

28. Pouco se conhece do percurso infantil e juvenil de D. Leonor. Órfã de pai aos quatro anos e separada da mãe aos seis, aquando da sua partida para o exílio em Castela, sabe-se que foi entregue pelo regente D. Pedro a D. Guiomar de Castro, mulher de D. Álvaro Gonçalves de Ataíde, que serviu a infanta como aia. Quando atingiu a maioridade dos catorze anos, D. Leonor dispôs de casa própria, com donzelas, oficiais e criados, embora tenha continuado a residir com as irmãs D. 
Catarina e D. Joana no paço de S. Bartolomeu, em Lisboa. Veja-se COELHO, Maria Helena da Cruz D. Leonor de Portugal: a imperatriz, 1434-1467. Vila do Conde: QuidNovi, 2011, pp. 16-22.

29. A respeito do nascimento das duas filhas mais novas de D. Duarte e D. Leonor da Aragão, sabemos que D. Catarina foi dada a luz a 25 de Novembro de 1436 e D. Joana a 20 de Março de 1439. Veja-se RODRIGUES, Ana Maria S. A. - As tristes rainhas. Leonor de Aragão. Isabel de Coimbra. Lisboa: Círculo de Leitores, 2012, pp. 105-107.

30. MORENO, Humberto Baquero - A Batalha e Alfarrobeira, vol 1, pp. 403-428.

31. PAVIOT, Jacques - Portugal et Bourgogne au XVe siècle (1384-1482). Lisboa: Comissão Nacional para as Comemorações dos Descobrimentos Portugueses; Paris: Centre Culturel Calouste Gulbenkian, 1995, pp. 44-45.

32. MARQUES, António Henrique de Oliveira; SERRÃO, Joel (Dirs.) - Nova História de Portugal. Vol. 4, p. 326.

33. MARQUES, A. H. de Oliveira - Hansa e Portugal na Idade Média. Lisboa: [s. n.], 1959, pp. 34-61.

34. No contexto da complexificação da prática da diplomacia nos finais da Idade Média, conseguimos observar através do Livro Vermelho, que data de 1471, como ao sacro imperador era reconhecida precedência sobre todos os monarcas, doges e senhores ao nível do tratamento epistolar e da recepção de embaixadas. Veja-se Trellado do liuro vermelho de tempo Dell Rey Dom afo [n]so o quinto. [1471]., fl. 24 v. Fonte manuscrita disponível em: https://bdigital.sib.uc.pt/bg1/ UCBG-Cofre-21/UCBG-Cofre-21_item1/index.html

35. PINA, Rui de - "Crónica de D. Afonso V". in Crónicas de Rui de Pina, cap. CXXXI, p. 759.

36. Segundo E. A. Strasen e Alfredo Gândara, mais que a descrição das virtudes psicológicas de D. Leonor, terá sido o retrato da infanta executado pelo pintor que acompanhou a embaixada imperial na viragem de 1448 para 1449 a impressionar Frederico III, rendido à beleza meridional da princesa. Veja-se STRASEN, E. A.; GÂNDARA, Alfredo - "Uma portuguesa imperatriz da Alemanha", p. 69.

37. PINA, Rui de - “Crónica de D. Afonso V". in Crónicas de Rui de Pina, cap. CXXXI, p. 759.

38. COELHO, Maria Helena da Cruz - D. Leonor de Portugal, a imperatriz (1434-1467), p. 27.

39. Princesas de Portugal: contratos matrimoniais dos séculos XV e XVI. Trad. Aires A. Nascimento. Lisboa: Cosmos, 1992, pp. 65-66.

40. Filho do desembargador e chanceler-mor de D. João I, doutor Fernando Afonso Silveira, João Fernandes da Silveira seguiu as pegadas do pai com uma notável carreira na burocracia régia. Formado em leis, foi desembargador, vice-chanceler, chanceler-mor, chanceler da Casa do Cível e regedor da Casa da Suplicação no reinado de D. Afonso V. Pela sua reconhecida competência, argúcia e lealdade, o monarca confiou-lhe por cerca de dez vezes a missão de o representar em cortes estrangeiras. Veja-se RAU, Virgínia - "Relações diplomáticas de Portugal durante o reinado de D. Afonso V". in Estudos de História Medieval. Lisboa: Editorial Presença, 1986, p. 71. Veja-se ainda, para um conhecimento mais profundo do oficialato régio em meados de Quatrocentos: FREITAS, Judite Antonieta Gonçalves de - "Teemos por bem e mandamos": a burocracia régia e os seus oficiais em meados de Quatrocentos (1439-1460). 2 vol. Cascais: Patrimonia, 2001.

41. Princesas de Portugal: contratos matrimoniais dos séculos XV e XVI, p. 65.

42. COELHO, Maria Helena da Cruz - "A política matrimonial da dinastia de Avis", p. 48.

43. Princesas de Portugal: contratos matrimoniais dos séculos XV e XVI, pp. 63-67.

44. HANREICH, Antonia - “D. Leonor de Portugal”, p. 14.

45. Princesas de Portugal: contratos matrimoniais dos séculos XV e XVI, p. 67.

46. Princesas de Portugal: contratos matrimoniais dos séculos XV e XVI, pp. 67-69.

47. O cumprimento do dote, ao contrário do estabelecido, arrastar-se-ia ao longo de décadas, acabando de ser totalmente pago quando passavam mais de trinta anos sobre o casamento, em 1487, com a entrega de 28.000 ducados de ouro, adiantados pelo mercador Duarte Brandão a D. João II, junto de Maximiliano, ainda herdeiro do Sacro Império. Veja-se VITERBO, Sousa - D. Leonor de Portugal, imperatriz da Alemanha, pp. 36-41. 
48. Princesas de Portugal: contratos matrimoniais dos séculos XV e XVI, pp. 89-93.

49. Princesas de Portugal: contratos matrimoniais dos séculos XV e XVI, pp. 63-86.

50. SOUSA, Armindo de - As Cortes medievais portuguesas (1385-1490). Vol. 1. Porto: Instituto Nacional de Investigação Científica, 1990, p. 372.

51. PINA, Rui de - “Crónica de D. Afonso V”. in Crónicas de Rui de Pina, cap. CXXXI, p. 759.

52. MORENO, Humberto Baquero - A Batalha e Alfarrobeira, vol. 2, p. 229.

53. SOUSA, Armindo de - As Cortes medievais portuguesas (1385-1490), pp. 372-373.

54. Princesas de Portugal: contratos matrimoniais dos séculos XV e XVI, pp. 85-87.

55. VALCKENSTEIN, Nicolau Lanckman de - Leonor de Portugal, imperatriz da Alemanha: Diário de viagem do embaixador Nicolau Lanckmen de Valckenstein. Trad. Aires A. Nascimento. Lisboa: Cosmos, 1992 , p. 18

56. COELHO, Maria Helena da Cruz - D. Leonor de Portugal, a imperatriz (1434-1467), p. 32.

57. PINA, Rui de - "Crónica de D. Afonso V". in Crónicas de Rui de Pina, cap. CXXXI, p. 759.

58. VALCKENSTEIN, Nicolau Lanckman de - Leonor de Portugal, imperatriz da Alemanha: Diário, pp. 19-25.

59. PINA, Rui de - "Crónica de D. Afonso V". in Crónicas de Rui de Pina, cap. CXXXI, p. 760.

60. VALCKENSTEIN, Nicolau Lanckman de - Leonor de Portugal, imperatriz da Alemanha: Diário, pp. 28-29.

61. PINA, Rui de - "Crónica de D. Afonso V". in Crónicas de Rui de Pina, cap. CXXXI, p. 760.

62. VALCKENSTEIN, Nicolau Lanckman de - Leonor de Portugal, imperatriz da Alemanha: Diário, p. 29.

63. VALCKENSTEIN, Nicolau Lanckman de - Leonor de Portugal, imperatriz da Alemanha: Diário, p. 31.

64. VALCKENSTEIN, Nicolau Lanckman de - Leonor de Portugal, imperatriz da Alemanha: Diário, p. 31.

65. PINA, Rui de - “Crónica de D. Afonso V”. in Crónicas de Rui de Pina, cap. CXXXI, p. 760.

66. PINA, Rui de - “Crónica de D. Afonso V". in Crónicas de Rui de Pina, cap. CXXXI, p. 760.

67. VALCKENSTEIN, Nicolau Lanckman de - Leonor de Portugal, imperatriz da Alemanha: Diário, p. 31.

68. PINA, Rui de - "Crónica de D. Afonso V". in Crónicas de Rui de Pina, cap. CXXXI, p. 761.

69. VALCKENSTEIN, Nicolau Lanckman de - Leonor de Portugal, imperatriz da Alemanha: Diário, p. 33.

70. COELHO, Maria Helena da Cruz - D. Leonor de Portugal, a imperatriz (1434-1467), p. 38.

71. RAMOS, Manuel - "Os membros da Geração de Avis: amizades, inimizades e falta de exemplaridade". in Symbolon I: Amor e Amizade. Porto: Universidade do Porto, 2009, pp. 102-106

72. COELHO, Maria Helena da Cruz - D. Leonor de Portugal, a imperatriz (1434-1467), pp. 40-41.

73. VALCKENSTEIN, Nicolau Lanckman de - Leonor de Portugal, imperatriz da Alemanha: Diário, p. 33.

74. COELHO, Maria Helena da Cruz - D. Leonor de Portugal, a imperatriz (1434-1467), p. 47.

75. COELHO, Maria Helena da Cruz - "A política matrimonial da dinastia de Avis", pp. 54-56.

76. $O$ documento que identifica a carraca que transportou $D$. Leonor, constante da chancelaria de D. João II, encontra-se transcrito em: VITERBO, Sousa - D. Leonor de Portugal, imperatriz da Alemanha, p. 8.

77. A escolha de D. Afonso para chefiar a comitiva portuguesa poderia estar relacionada, em parte, com o facto de já ter liderado uma importante embaixada na Península Itálica, aquando do Concílio de Basileia. Veja-se OLIVEIRA, António Resende de - “'Mais de pedras que de livros': D. Afonso, 4. Conde de Ourém, e a cultura nobiliárquica do seu tempo". in ANDRÉ, Carlos Ascenso (Coord.) - D. Afonso, 4. ․ Conde de Ourém e a sua época. Ourém: Câmara Municipal de Ourém, 2004, pp. 293-310.

78. COELHO, Maria Helena da Cruz - "A política matrimonial da dinastia de Avis", p. 57.

79. PINA, Rui de - "Crónica de D. Afonso V". in Crónicas de Rui de Pina, cap. CXXXII, p. 762; VALCKENSTEIN, Nicolau Lanckman de - Leonor de Portugal, imperatriz da Alemanha: Diário, pp. 51-69.

80. VALCKENSTEIN, Nicolau Lanckman de - Leonor de Portugal, imperatriz da Alemanha: Diário, p. 69. 81. Elaborada no quadro de um autêntico "serviço de informações" da diplomacia portuguesa, a carta em que D. Lopo de Almeida descreve o encontro entre D. Leonor e Frederico III para D. 
Afonso V, data de 28 de Fevereiro de 1452. Veja-se ALMEIDA, Lopo de - Cartas de Itália. Ed. lit. Rodrigues Lapa. Lisboa: Imprensa Nacional - Casa da Moeda, 1935, pp. 1-5. Mais recentemente, vieram a ser descobertas mais cinco cartas enviadas desta viagem para o rei português de D. Lopo de Almeida (três das quais repetidas; duas verdadeiramente novas) e uma outra de Luís Gonçalves Malafaia. Veja-se - ASKINS, Arthur L-F.; SCHAFFER, Martha E.; SHARRER, Harvey L. - "A New Set of Cartas de Itália to Afonso V of Portugal from Lopo de Almeida and Luís Goncalves Malafaia". Romance Philology 57 (2003), pp. 71-88.

82. Para observar a obra do pintor Bernardino di Betti (1454-1513), mais conhecido por Pinturicchio, veja-se a Figura 3 deste trabalho. Note-se que, depois desta pintura, foram produzidos em Itália outros trabalhos iconográficos alusivos a este matrimónio, designadamente: um painel conservado em Bath (destruído durante a Segunda Guerra Mundial), em Inglaterra, de que só resta uma fotografia a preto e branco, representando a chegada de Leonor por navio no então porto de Pisa; e uma outra pintura, hoje no Museu de Arte de Worcester, em Massachusetts, apresentando um painel frontal e dois painéis laterais que representam cenas da época do casamento e da coroação em Roma. Veja-se BASKINS, Cristelle - "The Triumph of Marriage: Frederick III and Leonora of Portugal, 1452". in The Triumph of Marriage: Painted Casonni of the Renaissance. Boston: Isabella Stewart Gardner Museum, 2009, pp. 47-65.

83. ALMEIDA, Lopo de - Cartas de Itália, p. 3.

84. ALMEIDA, Lopo de - Cartas de Itália, p. 5.

85. COELHO, Maria Helena da Cruz - "A política matrimonial da dinastia de Avis", p. 62.

86. PINA, Rui de - “Crónica de D. Afonso V”. in Crónicas de Rui de Pina, cap. CXXXII, p. 762.

87. ALMEIDA, Lopo de - Cartas de Itália, pp. 6-20

88. ALMEIDA, Lopo de - Cartas de Itália, p. 12.

89. PINA, Rui de - “Crónica de D. Afonso V". in Crónicas de Rui de Pina, cap. CXXXIII, p. 764.

90. VALCKENSTEIN, Nicolau Lanckman de - Leonor de Portugal, imperatriz da Alemanha: Diário, p. 77.

91. COELHO, Maria Helena da Cruz - "A política matrimonial da dinastia de Avis", pp. 64-65.

92. Nicolau Lanckman, a respeito da consumação do matrimónio, limita-se a referir que, ornamentado o quarto nupcial, os esposos ficaram a sós. Veja-se VALCKENSTEIN, Nicolau Lanckman de - Leonor de Portugal, imperatriz da Alemanha: Diário, p. 81.

93. A carta de D. Lopo de Almeida ao rei relatando a consumação do matrimónio data de dois dias depois do acto, 18 de Abril de 1452, assim atestando a sua importância. Veja-se ALMEIDA, Lopo de - Cartas de Itália, p. 28.

94. ALMEIDA, Lopo de - Cartas de Itália, pp. 21-31.

95. Adriana Almeida, que estudou a vida de D. Leonor no Império, refere que a irmã de D. Afonso $\mathrm{V}$ tinha um espirito jovial, comunicativo e impulsivo, por oposição a um marido que se revelava circunspecto, ponderado e calculista. Segundo a mesma autora, embora a imperatriz não deva ter sido vítima de maus tratos físicos, parece evidente que sofreu de falta de apoio e conforto de gente familiar, a avaliar pelas suas cartas para o rei português. Veja-se ALMEIDA, Adriana R. de "Perspectiva sobre a história das emoções", pp. 268-275.

96. COELHO, Maria Helena da Cruz - D. Leonor de Portugal, a imperatriz (1434-1467), pp. 79-88.

97. Lopo de Almeida refere o trato do sal em carta de 18 de Abril de 1452. ALMEIDA, Lopo de Cartas de Itália, p. 26.

98. Portugal passou a exportar regularmente vinho e frutas e o Sacro Império, em sentido contrário, cereais, ferro e manufacturas. Veja-se MARQUES, A. H. de Oliveira - Hansa e Portugal na Idade Média, pp. 60-65.

99. LOPES, Marília dos Santos - "Relações de Portugal com a Alemanha". in ALBUQUERQUE, Luís (Dir.) - Dicionário de História dos Descobrimentos Portugueses. Vol. 1. Lisboa: Caminho, 1994, pp. 44-48.

100. MENDONÇA, Manuela - As relações externas de Portugal nos finais da Idade Média. Lisboa: Colibri, 1994, pp. 93-118. 
101. Esta representação imortaliza o encontro do casal imperial, em 1452, às portas de Siena. Ao centro destacam-se Frederico III e D. Leonor, que envergam vestes com as cores imperiais (dourado e púrpura) e cingem à cabeça, respectivamente, uma coroa e uma tiara. À sua volta, numa lógica hierárquica, é representado em primeiro plano o arcebispo da cidade, que os abençoa, ao qual se segue um séquito de senhores, figurando por sua vez ao fundo uma hoste de cavaleiros e peões. No eixo do quadro, o artista pintou cuidadosamente uma coluna encimada, à esquerda, pelas armas do Sacro Império (a águia de duas cabeças) e, à direita, pelas de Portugal (o escudo das quinas, com a orla de castelos).

102. GOMES, Saul António - D. Afonso V, o Africano. Lisboa: Círculo de Leitores, 2006, p. 116.

\section{RESUMOS}

Nos finais da Idade Média, a jovem dinastia de Avis, depois de se unir por laços de sangue à Inglaterra, a Aragão e à Borgonha, aposta no tabuleiro da Cristandade numa ligação ao mais alto nível: o Sacro Império Romano-Germânico. Afinal, ao concretizar-se o casamento da infanta D. Leonor com Frederico III, entre 1451 e 1452, D. Afonso V joga não só um processo de afirmação da sua Coroa como de legitimação da sua linhagem, garantindo ao Rex Romanorum a indispensável noiva para estabelecer a Casa dos Habsburgo no trono imperial. O desenvolvimento da historiografia das relações internacionais medievas, nas últimas décadas, deu o mote para observarmos a aproximação política daqueles dois reinos, geograficamente distantes, a partir de um importante casamento régio, que nos legou um considerável conjunto de fontes (narrativas, documentais e iconográficas). Assim, num primeiro momento, procuraremos analisar as dinâmicas das alianças que, numa Cristandade em mudança, resultaram naquele interesse matrimonial; numa segunda fase, considerando os progressos da diplomacia àquele tempo, seguiremos o processo negocial do enlace entre as Coroas; por último, observaremos as distintas fases do casamento régio, de Portugal à Península Itálica, perspectivando um novo ciclo de relações entre as dinastias de Avis e de Habsburgo.

In the late Middle Ages, the young dynasty of Avis, after linked by kinship to England, Aragon and Burgundy, attempts to create in the space of Christianity a connection at the highest level: the Holy Roman Empire. With the marriage of the princess Leonor and Frederick III, arranged between 1451 and 1452, king Afonso V played not only with a process of affirmation of his Crown but also with the legitimation of his lineage, granting the Rex Romanorum the right bride to establish the Habsburg House on the imperial throne. The development of the historiography of medieval international relations in the last decades has given the pretext to observe the political approximation of those two kingdoms, geographically distant, based on an important royal marriage that has given us a considerable set of primary sources (chronicles, documents and iconography). Initially, we will try to analyze the dynamics of the alliances that have resulted in that matrimonial interest; in a second phase, considering the progress of diplomacy, we will follow the negotiation process between the Crowns; finally, we will observe the different phases of royal marriage (from Portugal to Italy), which foresee a new cycle of relations between the Avis and Habsburg dynasties. 
ÍNDICE

Keywords: History of International Relations, Medieval Diplomacy, Royal Weddings, Princess Leonor of Portugal, Emperor Frederick III

Palavras-chave: História das Relações Internacionais, Diplomacia Medieval, Casamentos Reais, infanta D. Leonor de Portugal, imperador Frederico III

\section{AUTOR}

\section{ANTÓNIO MARTINS COSTA}

Universidade de Coimbra, Faculdade de Letras

Centro de História da Universidade de Lisboa, 3004-530, Coimbra, Portugal antonio_martinscosta@hotmail.com 